\title{
Behavioral Effects of Levonantradol and Nantradol in the Rhesus Monkey
}

ALICE M. YOUNG, Ph.D., JONATHAN L. KaTZ, Ph.D, and JAMES H. WOODS, Ph.D. Ann Arbor, Mich.

\begin{abstract}
In rhesus monkeys, acute administration of levonantradol and nantradol produced signs of CNS depression, including ataxia with body sag, pupil dilation, ptosis, dozing, and reduced responsivity to external stimuli. Neither compound suppressed the morphine withdrawal syndrome; however, both alleviated the chronic abdominal contraction associated with withdrawal. The directly observable effects of these compounds were not antagonized by naloxone. When levonantradol was administered every 6 hours, marked tolerance developed to both the effects of levonantradol and nabilone and THC. No signs of withdrawal were observed when levonantradol injections were abruptly discontinued. When substituted in lieu of codeine under an intravenous drug self-administration procedure, neither levonantradol nor nantradol maintained responding at rates higher than those maintained by their vehicle. Finally, the discriminative effects of levonantradol were not equivalent to those of the narcotics ethylketazocine or etorphine.
\end{abstract}

$\mathrm{C}$ Tannabinoids have potential therapeutic applications in the treatment of glaucoma, asthma, nausea and vomiting associated with cancer chemotherapy, and pain. ${ }^{1}$ Widespread recreational use of marihuana, however, raises questions about whether the potential for abuse of novel cannabinoids may limit their usefulness as therapeutic agents. At present, there are no generally accepted protocols for the preclinical evaluation of the abuse liability of cannabinoids. In the absence of such protocols, and in the absence of standards of reference, the present study evaluated two cannabinoids in the rhesus monkey under procedures useful in evaluating abuse liability of narcotic analgesics.

The comparison of narcotics and cannabinoids is of interest, since there are some similarities in their various actions. For instance, a number of studies ${ }^{2 \rightarrow}$ suggest that $\Delta^{9}$-tetrahydrocannabinol (THC) has some analgetic effects in rodents under a variety

From the Department of Pharmacology, University of Michigan Medical School, Ann Arbor, Mich. 48109. of procedures. Some cannabinoids, although perhaps not THC, may have analgesic actions in humans. ${ }^{6}$ Additionally, cannabinoids have been suggested to suppress the withdrawal syndrome produced by morphine deprivation in rodents and primates. ${ }^{7,8}$

In the present study, levonantradol and nantradol, two potent cannabinoids with therapeutic potential, ${ }^{9}$ were assessed for capacity to suppress withdrawal signs in the 14-hour withdrawn morphine-dependent rhesus monkey. In addition, the grossly observable effects induced by levonantradol were studied in normal, nondependent monkeys and in nondependent monkeys treated with the narcotic antagonist naloxone. The effects of levonantradol were also evaluated in monkeys trained with etorphine or ethylketazocine as discriminative stimuli. ${ }^{10,11}$ Previous studies ${ }^{12,13}$ in rodents have shown that the discriminative effects of cannabinoids (e.g., THC) are distinct from those of a variety of other classes of CNS-active agents, including narcotics. 


\section{BEHAVIORAL EFFECTS OF LEVONANTRADOL}

The present study extended those studies to primates and to a distinct type of narcotic agonist, ethylketazocine, that has discriminative effects that are different from those of morphine. ${ }^{11}$ Further, the ability of nantradol and levonantradol to maintain responding in rhesus monkeys trained to self-administer codeine ${ }^{14}$ was assessed. A variety of narcotic agonists with abuse liability are self-administered by monkeys under many conditions ${ }^{15}$; however, it has been found generally that THC fails to maintain more responding than that maintained by its vehicle. ${ }^{16-18}$ Finally, the development of tolerance and dependence upon repeated administration of levonantradol was assessed. Tolerance to some of the behavioral effects of THC and morphine can be quite pronounced ${ }^{19,20}$; however, there is only a single report ${ }^{21}$ of dependence development to THC in nonhuman primates.

\section{Methods}

\section{Dependence and Tolerance Studies}

Suppression of Morphine Withdrawal. Male and female rhesus monkeys weighing 2 to $5 \mathrm{~kg}$ were trained to routinely receive morphine injections and were maintained on a regular schedule of injections $(3 \mathrm{mg} / \mathrm{kg}$ every 6 hours) that produces physiologic dependence in this species. ${ }^{22}$ The monkeys were housed in groups of four to six in wire mesh pens measuring $1.2 \mathrm{~m}$ by $1.5 \mathrm{~m}$ by 2.1 $\mathrm{m}$; the floor of each pen was covered with wood shavings. The monkeys were fed approximately 40 to $100 \mathrm{Gm}$ Purina Monkey Chow containing $608.3 \mathrm{Gm} /$ ton isoniazid daily. Drinking water was available at all times. The colony room was lit from 7 A.M. to 1 A.M. daily.

The procedures described by Deneau and Seevers $^{22}$ and Villarreal ${ }^{23}$ were used to assess the ability of cannabinoids to suppress the signs of morphine withdrawal. After at least three months of stabilization on the above schedule of morphine administration, injections were periodically withheld, which was followed by the development of withdrawal signs. Fourteen hours after the last morphine injection, when withdrawal signs are approximately half of the maximal severity, the cannabinoids, $3 \mathrm{mg} / \mathrm{kg}$ morphine, or vehicle were tested for their ability to relieve the withdrawal signs. Generally, morphine-like agonists suppress the withdrawal signs, whereas narcotic antagonists exacerbate those signs. In contrast to the morphine-like agonists, drugs identified as kappa agonists neither suppress nor exacerbate withdrawal signs; rather, these compounds at suitable doses produce a constellation of signs of sedation. ${ }^{24}$ Observations of the monkeys were made just prior to test injections at the first two half-hour intervals following the injection and at subsequent hourly intervals. When observations were complete and a withdrawal syndrome was still present, the monkeys were given $8.0 \mathrm{mg} / \mathrm{kg}$ morphine to terminate withdrawal. Three to four monkeys were studied at each dose. At each observation period, the maximum withdrawal or grade of sedation displayed by each monkey was determined by a trained observer who knew only a coded number and dose of the test compound the subject had received.

Acute and Chronic Effects of Levonantradol in Normal Monkeys. Male and female rhesus monkeys weighing 4 to $6 \mathrm{~kg}$ were trained to routinely receive injections and were housed, fed, and watered in a manner similar to that of the morphinedependent monkeys.

Following periodic injections of levonantradol, subjects were graded for direct effects according to a scale based on observations of effects of a variety of cannabinoids. Each subject was assigned a score of either 0,1 , or 2 for a particular effect depending on whether it was absent, present, or present and marked, respectively. The effects were pupil dilation, ptosis, ataxia and body sag, dozing, and a decrease in responsiveness to external stimuli. Since dozing never oc- 
YOUNG, KATZ, AND WOODS

TABLE I

Dose Schedule and Effects of Chronic Administration of Levonantradol in Rhesus Monkeys

\begin{tabular}{cccc}
\hline Day & $\begin{array}{c}\text { Injection } \\
\text { number* }\end{array}$ & $\begin{array}{c}\text { Per injection dose } \\
(\mathbf{m g} / \mathbf{k g})\end{array}$ & $\begin{array}{c}\text { Cannabinoid effect } \\
\text { score** }\end{array}$ \\
\hline 1 & 1 & 0.17 & 5.0 \\
4 & 2 & 0.3 & 6.0 \\
6 & 2 & 0.56 & 4.0 \\
9 & 2 & 1.0 & 4.0 \\
10 & 1 & 1.7 & 4.0 \\
15 & 2 & 3.0 & 0 \\
17 & 3 & 5.6 & 1.0 \\
19 & 3 & 10.0 & 0 \\
\hline
\end{tabular}

- Injections occurred every 6 hours starting at 7 A.M.; the 1 A.M. injection the following morning was considered the fourth of the day.

** Scoring of cannabinoid effects is described in the methods section; scores ranged from zero (no effect) to 10 (full effects). These scores are initial effects of the drug at 1 hour after administration.

curred throughout grading periods, it was always possible to grade each effect. Thus, each monkey received a score ranging from zero, representing no effect, to 10 , representing full effects.

Acute effects of levonantradol were determined with doses given no more frequently than once per 72 hours. High and low doses alternated so that two high doses were not administered in close succession. The doses studied were $0.03,0.1,0.17$, and $0.3 \mathrm{mg} / \mathrm{kg}$. Additionally, effects of 0.3 $\mathrm{mg} / \mathrm{kg}$ were studied in combination with $3.0 \mathrm{mg} / \mathrm{kg}$ naloxone. Selected doses of other compounds were studied in order to later estimate whether tolerance to effects of levonantradol conferred cross tolerance to effects of these compounds. The drugs and doses tested were $3.0 \mathrm{mg} / \mathrm{kg}$ THC, 0.56 $\mathrm{mg} / \mathrm{kg}$ nabilone, $0.1 \mathrm{mg} / \mathrm{kg}$ UM 1072 (a narcotic agonist of the kappa type), and 3.0 $\mathrm{mg} / \mathrm{kg}$ morphine. Following the determination of acute effects, injections of levonantradol were administered every 6 hours, starting at a dose of $0.17 \mathrm{mg} / \mathrm{kg}$ and increasing dosage whenever there was clear tolerance to the observable effects of the drug. The exact schedule of dose increments is provided in Table I. On the 14th, 15 th, and 16th days of chronic administra- tion, the monkeys were also injected with nalorphine, saline, and naloxone, respectively, and observed for any morphine-like withdrawal effects. The test with naloxone was repeated on the 21 st day. Following four days of stabilization on $10.0 \mathrm{mg} / \mathrm{kg}$ levonantradol every 6 hours, effects of still higher doses $(30.0$ and $100.0 \mathrm{mg} / \mathrm{kg}$ ) of levonantradol and of selected doses of additional compounds were assessed when administered in lieu of the second (1 P.M.) injection of the day. During these tests routine injections at the other times of the day continued. After the third injection on the 31st day of chronic levonantradol administration, all further injections were suspended, and the monkeys were observed for any signs of withdrawal.

\section{Intravenous Drug Self- Administration Studies}

Rhesus monkeys were conditioned to selfadminister codeine, and the ability of nantradol and levonantradol to maintain behavior was evaluated under a substitutional procedure. ${ }^{14}$ Monkeys were housed in fiber glass cubicles and fed approximately $150 \mathrm{Gm}$ Purina Monkey Chow daily. Water was available at all times. Each monkey 
received an isoniazid sugar cube (40 $\mathrm{mg} /$ cube) daily and fresh fruit several times per week.

Each monkey was prepared with a chronic indwelling siliconized rubber catheter implanted in a jugular, femoral, or brachial vein. To protect the catheter, the monkey wore a stainless steel harness ${ }^{25}$ that was connected by a jointed arm to the back of the experimental cubicle. The cath eter passed through the arm to an infusion pump, which delivered $1 \mathrm{ml}$ over 5 seconds. Mounted on the front panel of the cubicle were one green and two red stimulus lights and two response keys. Experimental conditions and data collection were arranged by a digital computer located in an adjacent room.

Drug injections were available during each of two daily 130-minute experimental sessions, which were separated by at least 4 hours. During each session, responses on the right lever were maintained under a fixed-ratio (FR) 30 , timeout 600-second schedule of intravenous injection of codeine $(0.32 \mathrm{mg} / \mathrm{kg}$ per injection). When the right green stimulus light was illuminated, 30 presses on the right lever (fixed-ratio, or FR, 30 schedule) produced a 5-second codeine infusion, during which the right stimulus light was out and the middle light was illuminated red. The infusion was followed by a 600-second timeout period, during which all stimulus lights were out and re sponses had no scheduled consequences. At the end of 600 seconds the right stimulus light was again illuminated, and the entire cycle was repeated. Each session terminated after 13 infusions or 130 minutes, whichever occurred first. During selected sessions the maintenance dose of codeine was replaced with saline, cannabinoid vehicle, or selected doses of the cannabinoids. Nantradol hydrochloride was substituted in injection doses of 0.001 to $0.1 \mathrm{mg} / \mathrm{kg}(2.11$ $\times 10^{-9}$ to $2.11 \times 10^{-7}$ mole $/ \mathrm{kg}$ ); levonantradol hydrochloride was substituted in injection doses of 0.001 to $0.032 \mathrm{mg} / \mathrm{kg}(2.11 \times$ $10^{-9}$ to 6.33 to $10^{-8} \mathrm{~mole} / \mathrm{kg}$ ). Two observa- tions of each dose were made in each of three monkeys. FR response rate (the rate of right lever presses during the FR component divided by the time elapsed from the onset of the FR component until solution delivery) and the number of infusions delivered were recorded for each experimental session.

\section{Discriminative Effects of Levonantradol}

The discriminative stimulus properties of levonantradol were compared to those of ethylketazocine and etorphine in the monkey. Rhesus monkeys were reduced to approximately 85 per cent of their ad libitum feeding weights (7.5 to $9.0 \mathrm{~kg}$ ) and provided with sufficient Purina Monkey Chow after each session to maintain these weights. All monkeys were housed individually, with water freely available. For experimental testing, the monkeys were transported from their individual home cages and restrained in the experimental chambers by primate chairs. The experimental chambers were equipped with two response levers mounted equidistant from a central food receptacle. An exhaust fan was used for ventilation; white noise was provided by a speaker in the chamber to mask extraneous noises.

The intramuscular injection of ethylketazocine or etorphine was established as a discriminative stimulus for the food-reinforced responses of rhesus monkeys." Responses on the right or left response lever were reinforced by the delivery of a $300-\mathrm{mg}$ banana-flavored food pellet depending on whether drug or saline had been injected intramuscularly. The training dose of ethylketazocine $(0.01 \mathrm{mg} / \mathrm{kg})$ was administered 10 minutes before the session; the training dose of etorphine $(0.00032 \mathrm{mg} / \mathrm{kg})$ was administered 20 minutes before the session. Twenty consecutive responses on the appropriate lever were required for food delivery (FR 20 schedule); responses on the inappropriate lever reset the FR requirement for responses on the appropriate lever. Sessions ended after the delivery of 
75 food pellets or 1 hour, whichever occurred first. During training, saline and drug administrations alternated daily. Discriminative control met criterion if the subject (1) emitted less than 40 responses before the first food delivery and (2) distributed at least 90 per cent of the total session responses on the appropriate lever.

The ability of levonantradol to occasion drug-appropriate responding was determined during test sessions. During the test sessions, 20 consecutive responses on either the drug- or saline-appropriate lever were reinforced throughout the session, and the pretreatment time was extended to $30 \mathrm{~min}$ utes. Training days alternated with test days to ensure that discriminative responding was maintained. Whenever a monkey failed to achieve the discrimination criteria on a training day, further testing was postponed until these criteria were met on at least two consecutive days. A complete doseresponse function for levonantradol was obtained in two or three subjects to establish the extent to which it produced discriminative effects similar to those of the training drug. Dose-effect evaluations were conducted until either levonantradol produced an equivalent response to the training drug (e.g., over 90 per cent drugappropriate responding) or until doses were reached that markedly reduced the rate of responding during the test session. The order of doses tested in each subject was mixed. The number of responses on the drug-appropriate lever was expressed as a percentage of the total responses on both levers during the session, and the rate of responses on either lever during the entire session was expressed as a percentage of the rate of responding on saline training days.

\section{Drugs}

Codeine phosphate, morphine sulfate, UM $1072\left[( \pm)-\left(1 R / S, 5 R / S, 9 R / S, 2^{\prime \prime} R / S\right)-5,9-\right.$ $\alpha$-dimethyl-2'-hydroxy-2-tetrahydrofurfuryl 6 , 7-benzomorphan hydrochloride] and nal- oxone hydrochloride were dissolved in sterile isotonic saline. Nalorphine hydrochloride was dissolved in distilled water. Nantradol hydrochloride, levonantradol hydrochloride, and THC were suspended in a mixture of Emulphor, ethanol (95 per cent), and saline. Nabilone was suspended in a mixture of Tween 80 , ethanol (95 per cent), and water. For intravenous injection, solutions of cannabinoids were prepared in a concentration of $1.0 \mathrm{mg} / \mathrm{ml}$; lower concentrations were prepared by dilution with sterile saline. For intramuscular and subcutaneous injection, concentrations were prepared to deliver all doses in volumes no greater than $2 \mathrm{ml} / \mathrm{kg}$. Doses of THC and nabilone are expressed as the base; doses of other compounds are expressed as the salt.

\section{Results}

\section{Dependence and Tolerance Studies}

Suppression of Morphine Withdrawal. Neither nantradol $(0.2$ to $0.4 \mathrm{mg} / \mathrm{kg})$ nor levonantradol $(0.032$ to $0.56 \mathrm{mg} / \mathrm{kg}) \mathrm{com}$ pletely suppressed morphine withdrawal signs in the rhesus monkey (Table II). Interestingly, both compounds at suitable doses (levonantradol: 0.1 to $0.56 \mathrm{mg} / \mathrm{kg}$; nantradol: $0.2 \mathrm{mg} / \mathrm{kg}$ ) produced a relaxation of the abdominal musculature that is typically contracted during morphine withdrawal. At the highest dose of levonantradol tested $(0.56 \mathrm{mg} / \mathrm{kg})$, the abdominal relaxation was accompanied by a decrease in the responsivity of the subject to abdominal pressure that accompanies the contraction seen during withdrawal. Other signs of withdrawal, including restlessness, retching and vomiting, lying on the side, and skeletal muscle rigidity, were not alleviated by either compound. In sum, neither levonantradol nor nantradol produced a marked change in the normal progression of the withdrawal syndrome from morphine in the monkey as indicated by the overall withdrawal scores (Table II). In contrast, $3.0 \mathrm{mg} / \mathrm{kg}$ morphine sulfate 


\section{TABLE II}

\begin{tabular}{|c|c|c|c|c|}
\hline \multirow{3}{*}{$\begin{array}{l}\text { Drug and } \\
\text { dose }(\mathbf{m g} / \mathbf{k g})\end{array}$} & \multicolumn{4}{|c|}{ Withdrawal score* } \\
\hline & \multirow[t]{2}{*}{ Preinjection } & \multicolumn{3}{|c|}{ Postinjection } \\
\hline & & $\overline{1 \mathrm{hr}}$ & $2 \mathrm{hrs}$ & $3 \mathrm{hrs}$ \\
\hline \multicolumn{5}{|l|}{ Levonantradol } \\
\hline 0.03 & 4.0 & 4.5 & 4.6 & 4.9 \\
\hline 0.1 & 3.8 & 4.4 & 4.8 & 5.0 \\
\hline 0.3 & 4.0 & 4.8 & 5.1 & 5.1 \\
\hline 0.56 & 4.0 & 3.6 & 4.5 & 4.9 \\
\hline \multicolumn{5}{|l|}{ Nantradol } \\
\hline 0.2 & 4.4 & 4.5 & 5.0 & 5.0 \\
\hline 0.4 & 4.3 & 5.0 & 5.1 & 5.5 \\
\hline \multicolumn{5}{|l|}{ Morphine } \\
\hline 1.0 & 4.0 & 3.1 & 3.1 & 4.0 \\
\hline 3.0 & 4.1 & 1.4 & 1.4 & 1.1 \\
\hline 10.0 & 4.3 & 0 & 0 & 0 \\
\hline \multicolumn{5}{|l|}{ Vehicle } \\
\hline- & 3.7 & 4.2 & 4.5 & 4.7 \\
\hline
\end{tabular}

- Scores range from zero (no withdrawal signs) to 8 (severe withdrawal). Scoring of withdrawal is according to the scale developed by Deneau and Seevers ${ }^{22}$ and described by Villarreal. ${ }^{23}$ Average scores are based on single observations in three to four monkeys.

quickly produced complete or near-complete suppression of withdrawal.

Acute and Chronic Effects in Normal Monkeys. The acute effects of both nantradol and levonantradol were characterized by five major effects: pupil dilation, ataxia with body sag, ptosis, dozing, and reduced reactivity to external stimuli, including those from cagemates and human observers. There was also a decrease in locomotor activity possibly due to the ataxia, assumption of peculiar postures, and sometimes vacant staring. None of these effects was reversed by subcutaneous injection of $1.7 \mathrm{mg} / \mathrm{kg}$ naloxone, a dose that is capable of completely reversing opiate agonist effects (e.g., $5 \mathrm{mg} / \mathrm{kg}$ morphine).

Grades consisting of scores of the five major grossly observable effects of levonantradol, as described above, are shown as a function of dose in Figure 1. From the dose-effect function, the estimated dose of levonantradol to produce 50 per cent of the maximum effects was $0.13 \mathrm{mg} / \mathrm{kg}$. Nantradol was tested at a single dose $(0.4$ $\mathrm{mg} / \mathrm{kg}$ ), which produced full effects in all subjects (a score of 10). As with levonantradol, effects of nantradol were not affected by naloxone. Doses of THC and nabilone produced similar effects, scores of which are given in Table III ("before" column). Effects of both UM 1072 and morphine are also shown. While UM 1072 produced some effects resembling those of the cannabinoids (e.g., pupil dilation), the effects of morphine were generally different, accounting for the low score at a behaviorally active dose. With $3.0 \mathrm{mg} / \mathrm{kg}$ morphine, there was little ataxia and dozing, only slight decreases in responsivity to external stimuli, and no ptosis. Additionally, there was staring, scratching, and rubbing of the eyes. 


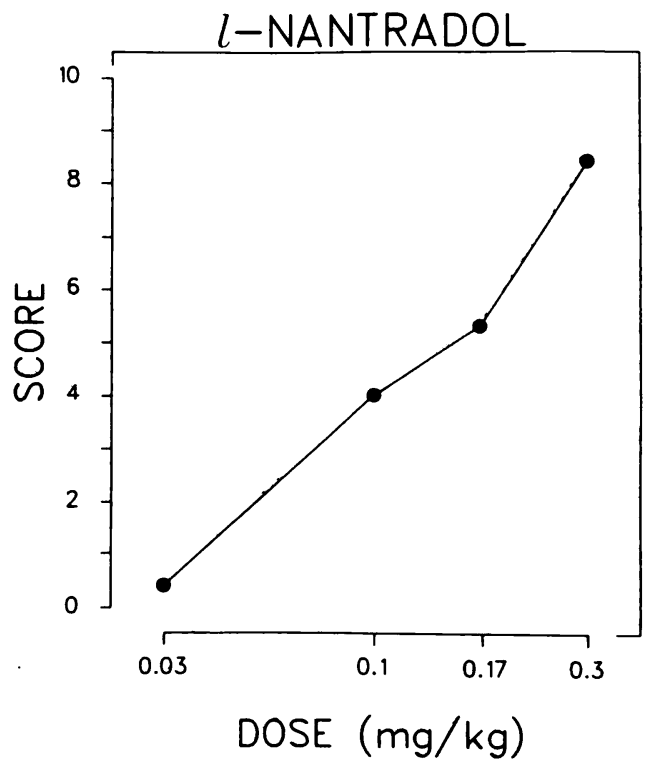

Fig. 1. Effects of levonantradol on grossly observ. able effects in rhesus monkeys. Scores were assigned according to the scale described in the text. Each point is typically the mean of one ob. servation at each dose in each of three monkeys. See text for further details.

Table I shows the schedule of dose increments over the course of chronic levonantradol administration; dose increments were made in one-quarter log units when complete or near complete (score between 0 and 1) tolerance developed to the effects of the lower dose. As can be seen in Table I, the first four-dose increments produced effects approximating those seen initially. Following the development of tolerance at 1.7 $\mathrm{mg} / \mathrm{kg}$ per injection, however, it was not possible to recapture the initial effects of levonantradol with further dose increments. At the highest dose that was administered every 6 hours $(10.0 \mathrm{mg} / \mathrm{kg})$, there was virtually complete tolerance to all of the effects seen during acute administration of levonantradol (Table III, column labeled "during"). Substitutions of still higher doses (30.0 and $100.0 \mathrm{mg} / \mathrm{kg})$ also did not produce any substantial effects, indicating a pronounced tolerance to the effects of levonantradol. Additionally, there was cross tolerance to the effects of THC and nabilone (Table III). Doses of these cannabinoids that earlier had produced nearly full effects on the scale no longer produced any effects.

In contrast to the pronounced tolerance to effects of the cannabinoids, there was relatively little if any cross tolerance to effects of the narcotics UM 1072 and mor-

\section{TABLE III}

Effects of Levonantradol, THC, Nabilone, UM 1072, and Morphine on Grossly Observable Behavior in

Rhesus Monkeys Before and During Repeated Levonantradol Administration*

\begin{tabular}{ccc}
\hline & \multicolumn{2}{c}{ Cannabinoid effect scores } \\
\cline { 2 - 3 } Drug and dose (mg/kg) & Before & During \\
\hline Levonantradol & & \\
0.17 & 5.3 & 1.0 \\
0.30 & 8.3 & 3.0 \\
0.56 & - & 2.0 \\
1.0 & - & 3.0 \\
1.7 & - & 0.0 \\
3.0 & - & 0.3 \\
5.6 & - & 0.3 \\
10.0 & - & 0.0 \\
30.0 & - & 1.3 \\
100.0 & - & 1.0 \\
THC & & \\
3.0 & 8.7 & 0.0 \\
Nabilone & & \\
0.56 & 9.0 & 0.0 \\
UM 1072 & & \\
0.10 & 7.1 & 0.0 \\
0.30 & - & 6.3 \\
Morphine & & \\
3.0 & 3.0 & 1.0 \\
\hline
\end{tabular}

- Scoring of enosely obeervable effects is described in the methods section; ecores ranged from zero (no effect) to 10 (full effect). Scores in the column labeled "before" represent the mean of obeervations in at least two, and typically three, animals before the initiation of repeated levonantradol injections. Scores in the column labeled "during" represent the mown of observations in at least three animals during repented levonantradol injections. Scores in the column labelled "during" at doses up to 10 $\mathrm{mg} / \mathrm{kg}$ levonantradol are the final ecores for that dowe during the repeated injection regimen; Bcores for levonantradol doses greater than $10 \mathrm{mg} / \mathrm{kg}$ and for THC, nabilone, UM 1072, and morphine are for single obeer vations in each of three monkeys during repeated injections of $10 \mathrm{mg} / \mathrm{kg}$ levonantradol. 


\section{LEVONANTRADOL MCV 4161 \\ GRAND AVERAGE}

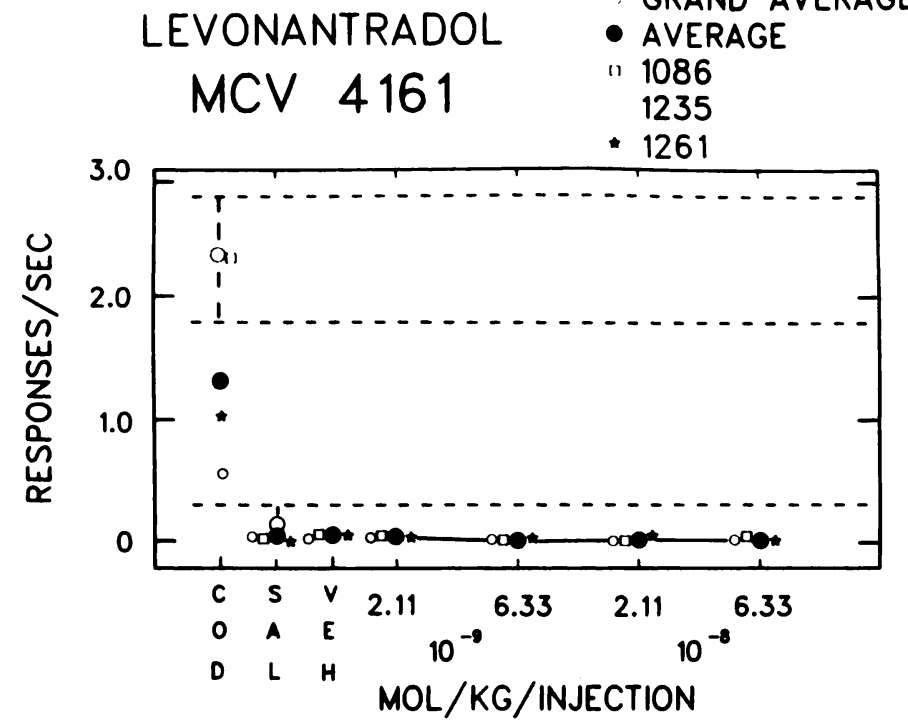
NANTRADOL
- GRAND AVERAGE
UM 1159
- AVERAGE
- 1261
- 1235
- 1086

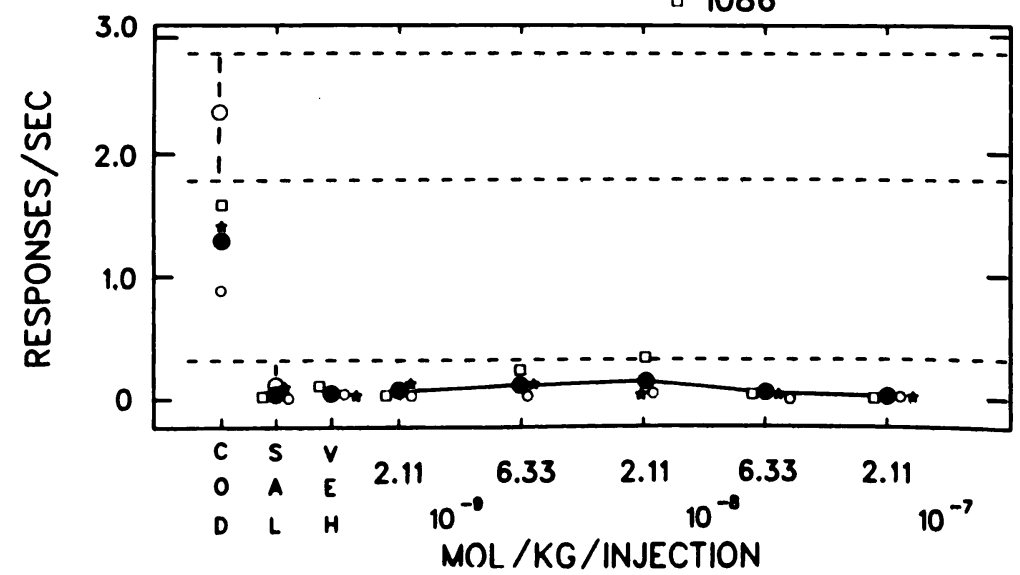

Fig. 2. Rates of responding maintained under a FR 30-second, TO 600-second schedule of intravenous drug injections under various conditions. The available injection was either $0.32 \mathrm{mg} / \mathrm{kg}$ codeine (COD), saline (SAL), vehicle (VEH: Emulphor, 95\% ethanol, and sterile water), or doses of levonantradol or nantradol. Doses of levonantradol and nantradol were substituted twice in each of three monkeys identified by the numbers and symbols in the upper right corners. The nantradol and levonantradol injection doses were $0.001,0.003,0.01$, and $0.03 \mathrm{mg} / \mathrm{kg}$ and, for nantradol, $0.1 \mathrm{mg} / \mathrm{kg}$. For each figure, the average (closed circles) represents the mean rate during two codeine baseline sessions or substitution test sessions for the three monkeys. Grand average (open circle) is a historical control value for responding of 20 monkeys under the $0.32 \mathrm{mg} / \mathrm{kg}$ codeine and saline conditions. Dashed lines give \pm 3 S.E.M. for the codeine average and +3 S.E.M. for the saline average. 

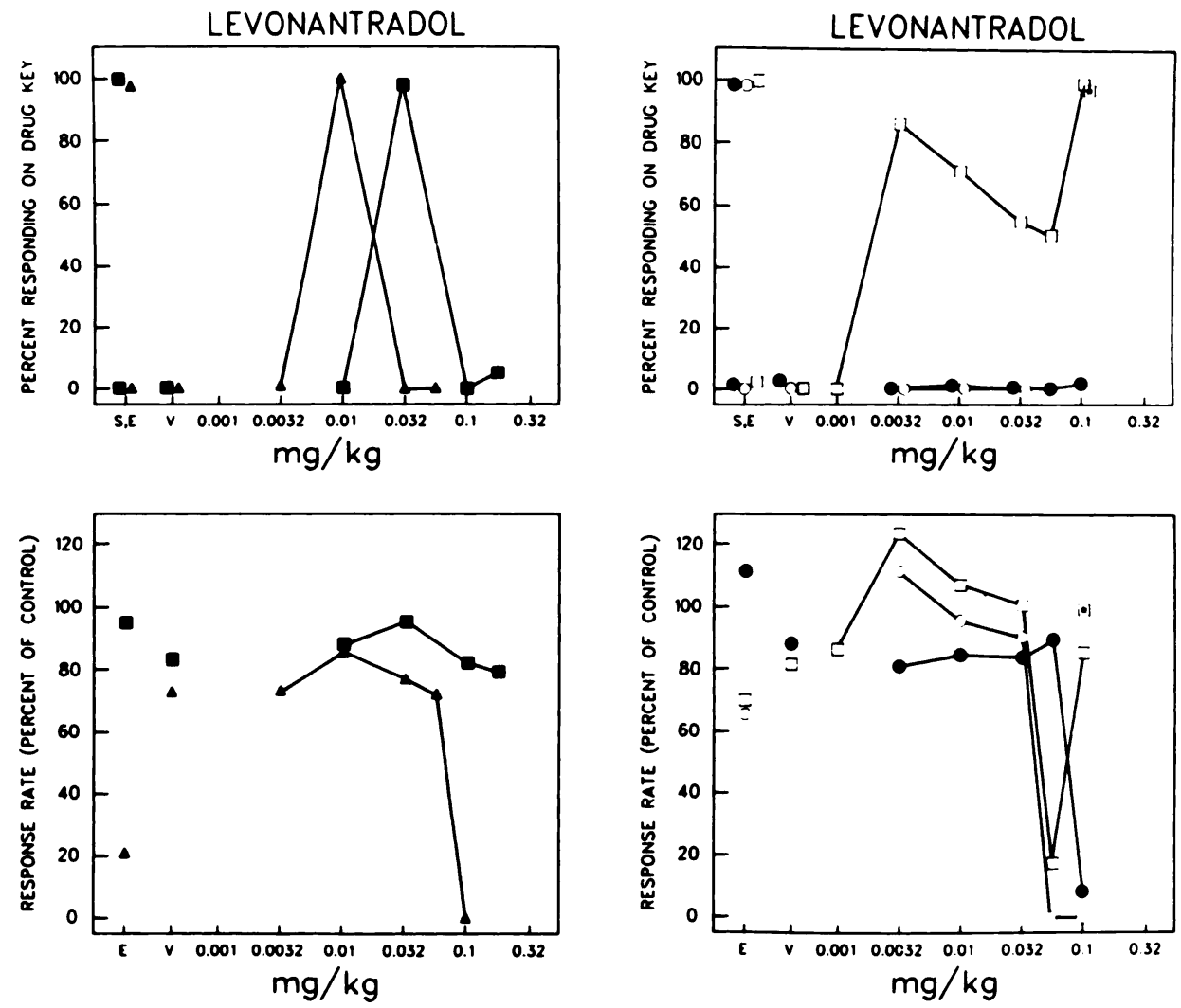

Fig. 3. Discriminative stimulus and rate-decreasing effects of levonantradol in rhesus monkeys. Etorphine $(0.00032 \mathrm{mg} / \mathrm{kg})$ or ethylketazocine $(0.01 \mathrm{mg} / \mathrm{kg})$ was established as a discriminative stimulus for food-maintained behavior in different groups of monkeys. Upper panel ordinates: Number of responses on the training drug-appropriate lever, expressed as percentage of the total session responses. Lower panel ordinates: Rate of responding, expressed as percentage of the response rate during saline training sessions. Abscissae: Doses of levona ntradol. Response distribution and rates following levonantradol vehicle are presented at $V$;performance during training sessions is presented at $S, E$ (upper panels) and $E$ (lower panels). Each levonantradol and vehicle data point represents a single determination in one monkey; each monkey is represented by a different symbol. The starred open square in the right panel represents a second determination in monkey 950 at 0.1 $\mathrm{mg} / \mathrm{kg}$.

phine. With UM 1072 there appeared to be a dampened response to $0.1 \mathrm{mg} / \mathrm{kg}$; however, $0.3 \mathrm{mg} / \mathrm{kg}$ produced effects comparable to those obtained earlier at the lower dose. Additionally, the effects of $3.0 \mathrm{mg} / \mathrm{kg}$ morphine, which were slight to begin with, were modified only to a small degree by the profound tolerance that developed to levonantradol (Table III). Moreover, other effects of morphine (e.g., scratching and rubbing the eyes) were still quite apparent in the animals tolerant to levonantradol.

Neither administration of the narcotic antagonists nalorphine (day 14) and naloxone (days 16 and 21) nor abrupt discontinuation of levonantradol injections (day 31) produced any clear signs of withdrawal. There was some irritability to handling after the discontinuance of levonantradol injections and a slight delay to eat food at the 
once-daily feedings. Normal monkeys typically begin eating at once when the food is given. The increases in latency to eat were at most only 8 minutes and lasted three to four days.

\section{Intravenous Drug Self- Administration Studies}

Nantradol and levonantradol did not maintain responding by rhesus monkeys experienced in self-administering codeine (Fig. 2). Over a 32- to 100-fold range of injection doses, nantradol and levonantradol maintained response rates and injection frequencies no higher than those maintained by either saline or the cannabinoid vehicle. Following injection of the highest tested doses of nantradol $(0.1 \mathrm{mg} / \mathrm{kg})$ and levonantradol $(0.032 \mathrm{mg} / \mathrm{kg})$, the monkeys were occasionally observed on closedcircuit TV to sit with their eyes closed and head dropped; no gross motor incoordination was observed. The monkeys continued to respond at usual rates for codeine injections during the intervening experimental sessions.

\section{Discriminative Effects of Levonantradol}

When the administration of narcotics served as discriminative stimuli for foodreinforced responding, levonantradol produced equivocal results (Fig. 3). In monkeys for which ethylketazocine served as a discriminative stimulus, one dose of levonantradol, $0.1 \mathrm{mg} / \mathrm{kg}$, occasioned drug-appropriate responding in one of three monkeys. At lower doses, levonantradol occasioned intermediate responding in this monkey. In the two other monkeys for which ethylketazocine served as a discrim. inative stimulus, levonantradol did not occasion ethylketazocine-appropriate responding at any dose, including doses that decreased rates of responding. In the monkeys for which etorphine served as a discriminative stimulus for food-maintained responses, levonantradol occasioned drug- appropriate responding at one dose. Lower and higher doses produced only salineappropriate responding.

\section{Discussion}

A number of recent studies have suggested that cannabinoids may be effective in alleviating opiate withdrawal signs in a variety of nonprimate species (see Siemens ${ }^{26}$ for a review, and papers by Gilbert and Lal et al. in this issue). In most previous studies, doses of THC that suppressed withdrawal signs were of a magnitude that produce general depressant effects that may have made the observation of withdrawal signs difficult. ${ }^{27}$ In a well-considered set of experiments, Frederickson et al. ${ }^{28}$ studied naloxone-precipitated withdrawal in guinea pigs and rats. Effects of THC on the withdrawal signs of guinea pigs were greater than those for rats. Additionally, the effects were stereospecific; the synthetic (+)-isomer was essentially inactive. Finally, in guinea pigs there was a clear separation of the effects of THC on withdrawal scores and the general depressant effects of the drug that was not seen with pentobarbitol. In contrast, the present experiments failed to find any effect of the cannabinoid levonantradol on most morphine withdrawal signs in the monkey, although an interesting selective alleviation of abdominal signs was observed. This selective effect on the abdominal musculature deserves further study. It appears, however, that whether or not cannabinoids selectively affect opiate withdrawal is largely dependent on the species studied.

The present findings of profound tolerance to effects of levonantradol are consistent with studies of tolerance to the effects of cannabinoids in both laboratory animals ${ }^{19}$ and humans. ${ }^{29}$ Additionally, tolerance to effects of levonantradol conferred cross tolerance to the effects of other cannabinoids, but only limited, if any, cross tolerance to the effects of opiates. Similar cross tolerance among cannabinoids but not opiates 
has been described in pigeons. ${ }^{19,30}$ Other workers ${ }^{21,31}$ have described tolerance and dependence development with chronic administration of THC, while only tolerance to levonantradol was observed in the present study. Signs of cannabinoid abstinence described in those studies, such as tremors occasionally involving the whole body, hyperirritablilty, yawning, and penile erection, were either not seen or not seen with any frequency indicative of a definite with drawal syndrome. Current studies are under way in order to determine whether withdrawal effects can be obtained in monkeys rendered tolerant to THC.

Levonantradol and racemic nantradol did not maintain responses leading to their intravenous injection in rhesus monkeys experienced in self-administering codeine. These results are consistent with previous reports ${ }^{16,17}$ that other cannabinoids, including THC, also do not serve as intravenous reinforcers under conditions sufficient to demonstrate the reinforcing properties of narcotics and central nervous system stimulants.

Levonantradol did not unequivocally share discriminative stimulus properties with the narcotics etorphine or ethylketazocine in the monkey. Response generalization to ethylketazocine occurred in only one of three monkeys, and response generalization to etorphine occurred only at intermediate doses of levonantradol. These patterns of discriminative effect are not characteristic of compounds that share discriminative and other pharmacologic effects with either ethylketazocine or etorphine in the monkey. ${ }^{10,11}$ Differences among subjects and a lack of dose dependence in the present study render interpretations of the results difficult. Other investigators ${ }^{12}$ have reported that THC does not share discriminative stimulus effects with the narcotic morphine in the rat and pigeon. In general, cannabinoids have been found to produce unique discriminative effects which are shared by other cannabinoids but not by members of other pharmacologic classes. $^{12,13}$

\section{Acknowledgments}

This research was supported by USPHS Grants DA 00254 and DA 00154. The authors thank F. Adams, J. Goodrich, and K. Watson for excellent technical assistance; Dr. K. Stephens for expert computer assistance; and Dr. G. M. Milne of Pfizer, Inc., for the gift of levonantradol and nantradol.

\section{References}

1. Cohen S. Therapeutic aspects. In: Petersen RC, ed., Marijuana Research Findings: 1980. NIDA Research Monograph 31. Washington, D.C.: U.S. Government Printing Office; 1980: 199-221.

2. Buxbaum GB. Analgesic activity of delta ${ }^{9}$-tetrahydrocannabinol in the rat and mouse. Psychopharmacologia (Berlin). 1972; 25:275-280.

3. Chesher GB, Dahl CJ, Everingham M, Jackson OM, Marchant-Williams $H$, Starmer GA. The effect of cannabinoids on intestinal motility and their antinociceptive effect in mice. $\mathrm{Br} J$ Pharmacol. 1973; 49:588-594.

4. Kaymakcalan S, Turker RK, Turker MN. Analgesic effect of delta ${ }^{9}$-tetrahydrocannabinol in the dog. Psychopharmacologia (Berlin). 1974; 35: 123-128.

5. Sofia RD, Nalepa SD, Harankal JJ, Vassar HB. Antiedema and analgesic properties of delta ${ }^{8}$-tetrahydrocannabinol. $J$ Pharmacol Exp Therap. 1973; 186:646-655.

6. Harris LS. Cannabinoids as analgesics. In: Beers RF, Bassett EG, eds., Mechanisms of Pain and Analgesic Compounds. New York: Raven Press; 1979:467-473.

7. Bhargava HN. Time course of the effects of naturally occurring cannabinoids on the morphine abstinence syndrome. Pharmacol Biochem Behav. 1978; 8:7-11. 
8. Aceto MD, Harris LS, Dewey WL, May EL. Annual report: dependence studies of new compounds in the rhesus monkey (1979). In: Harris LS, ed. Problems of Drug Dependence, 1979. NIDA Research Monograph 27. Washington, D.C.: U.S. Government Printing Office; 1979:330-350.

9. Milne GM, Koe BK, Johnson MR. Stereospecific and potent analgetic activity for nantradol, a structurally novel, cannabinoid-related analgetic. In: Harris LS, ed., Problems of Drug Dependence, 1979. NIDA Research Monograph 27, Washington, D.C.: U.S. Government Printing Office; 1979: 84-92.

10. Hein DW, Young AM, Herling S, Woods JH. Pharmacological analysis of the discriminative stimulus characteristics of ethylketazocine in the rhesus monkey.J Pharmacol Exp Therap. In press.

11. Herling S, Woods JH. Discriminative effects of etorphine in rhesus monkeys. Psychopharmacology. In press.

12. Weissman A. Generalization of the discriminative stimulus properties of delta ${ }^{2}$-tetrahydrocannabinol to cannabinoids with therapeutic potential. In: Colpaert FC, Rosecrans JA, eds. Stimulus Properties of Drugs: Ten Years of Progress. Amsterdam: Elsevier North-Holland Biomedical Press; 1978:99-122.

13. Balster RL, Ford RD. The discriminative stimulus properties of cannabinoids: a review. In: Ho, BT, Richards DW, Chait DL, eds., Drug Discrimination and State-Dependent Learning. New York: Academic Press; 1978: 131-147.

14. Woods JH. Narcotic-reinforced responding: a rapid evaluation procedure. Drug and Alcohol Dependence. 1980; 5:223-230.

15. Woods JH, Young AM, Herling S.: Classification of narcotics on the basis of their reinforcing, discriminative, and antagonist effects in rhesus monkeys. Fed Proc. In press.

16. Carney JM, Uwaydah IM, Balster RL. Evaluation of a suspension system for intravenous self-administration studies of water-insoluble compounds in the rhesus monkey. Pharmacol Biochem Behav. 1977; 7:357-364.

17. Harris RT, Waters W, McLendon D. Evaluation of reinforcing capability of delta ${ }^{9}$-tetrahydrocannabinol in rhesus monkeys. Psychopharmacologia. (Berlin) 1974; 37:23-29.

18. Pickens R, Thompson T, Muchow DC. Cannabis and phencyclidine self-administration by animals. In: Goldberg L, Hoffmeister F, eds., Bayer Symposium IV, Psychic Dependence. Berlin:Springer-Verlag; 1973:78-86.

19. McMillan DE, Dewey WL, Harris LS. Characteristics of tetrahydrocannabinol tolerance. Ann NY Acad Sci. 1971; 191:83-99.

20. Woods JH, Carney J. Narcotic tolerance and operant behavior. In: Krasnegor NA, ed., Behavioral Tolerance: Research and Treatment Implications. NIDA Research Monograph 18, Washington, D.C.: U.S. Government Printing Office; 1978:54-66.

21. Deneau GA, Kaymakcalan S. Physiological and psychological dependence to synthetic delta ${ }^{9}$-tetrahydrocannabinol (THC) in rhesus monkeys. The Pharmacologist. 1971; 13:246.

22. Deneau GA, Seevers MH. Evaluation of new compounds for morphine-like physical dependence capacity. In: Proceedings of the Committee on Problems of Drug Dependence, NAS. Washington, D.C. 1963:Addendum 25.

23. Villarreal JE. The effects of morphine agonists and antagonists in morphinedependent rhesus monkeys. In: Kosterlitz $\mathrm{H}$, Collier HOJ, Villarreal JE, eds., Agonist and Antagonist Actions of Narcotic Drugs. Baltimore:University Park Press; 1973:73-93.

24. Woods JH, Smith CB, Medzihradsky F, 
Swain HH. Preclinical testing of new analgesic drugs. In: Beers RF, Bassett EG, eds., Mechanisms of Pain and Analgesic Compounds. New York: Raven Press; 1979:429-445.

25. Deneau GA, Yanagita T, Seevers MH. Self-administration of psychoactive substances by the monkey. Psychopharmacologia. (Berlin) 1969; 16: 30-48.

26. Siemens AJ. Effects of cannabis in combination with ethanol and other drugs. In: Petersen RC, ed., Marijuana Research Findings: 1980. NIDA Research Monograph 31. Washington, D.C.: U.S. Government Printing Office; 1980:167-198.

27. Carder B. Blockade of morphine abstinence by delta ${ }^{9}$-tetrahydrocannabinol. Science (Washington). 1975; 190: 590-591.

28. Frederickson RCA, Hewes CR, Aiken JW. Correlation between the in vivo and an in vitro expression of opiate withdrawal precipitated by naloxone: their antagonism by $l(-)$-delta ${ }^{9}$-tetrahydrocannabinol. $J$ Pharmacol Exp Therap. 1976; 199:375-384.

29. Jones RT, Benowitz N. The 30-day trip-clinical studies of cannabis tolerance and dependence. In: Braude MC, Szara S, eds., The Pharmacology of Marihuana. New York: Raven Press; 1976:627-642.

30. McMillan DE, Ford RD, Frankenheim JM, Harris RA, Harris LS. Tolerance to active constitutents of marihuana. Arch Int Pharmacodyn Therap. 1972; 198:132-144.

31. Kaymakcalan S. Physiological and psychological dependence on THC in rhesus monkeys. In: Paton WDM, Crown J, eds., Cannabis and its Derivatives. London: Oxford University Press; 1972:142-149.

Reprint requests to: Dr. James H. Woods, Department of Pharmacology, University of Michigan Medical School, Ann Arbor, Mich. 48109. 